\title{
Stay-green ranking and maturity of corn hybrids: 1 . Effects on dry matter yield, nutritional value, fermentation characteristics, and aerobic stability of silage hybrids in Florida
}

\author{
K. G. Arriola, S. C. Kim, ${ }^{1}$ C. M. Huisden, ${ }^{2}$ and A. T. Adesogan ${ }^{3}$ \\ Department of Animal Sciences, Institute of Food and Agricultural Sciences, University of Florida, Gainesville 32608
}

\begin{abstract}
This study determined effects of maturity, stay-green (SG) ranking, and hybrid source on dry matter (DM) yield, nutritive value, fermentation, and aerobic stability of corn hybrids. One high stay-green (HSG) hybrid and one average stay-green (ASG) hybrid with similar relative maturity (117 d) from each of 2 seed companies (Croplan Genetics, St. Paul, MN; Pioneer Hi-Bred International, Des Moines, IA) were grown on $1-\times 6$-m plots at random locations within each of 4 blocks. The hybrids were harvested at 25, 32, and 37\% DM from each plot and separated into thirds for botanical fractionation and analysis, whole-plant chemical analysis, and ensiling. Chopped, whole plants were ensiled (8 kg) in quadruplicate in 20-L mini-silos for $107 \mathrm{~d}$. A splitplot design was used for the study. Yields of wholeplant and digestible DM and concentrations of starch and DM increased with maturity, whereas concentrations of crude protein, water-soluble carbohydrates, and neutral detergent fiber decreased. High SG hybrids had greater DM yield than ASG hybrids when harvested at 25 and $37 \%$, but not $32 \%$ DM. Unlike those from Croplan Genetics, the Pioneer HSG hybrid had greater ear and whole-plant DM concentration than their ASG hybrids. Stover moisture and CP concentration were greater among HSG versus ASG hybrids, particularly among Croplan Genetics hybrids. Croplan Genetics HSG hybrids had greater neutral and acid detergent fiber concentrations and lower in vitro DM digestibility in the unensiled whole-plant, the stover, and the silage than their ASG hybrids, whereas contrasting trends were evident for Pioneer hybrids. Silage fermentation indices were largely unaffected by hybrid SG ranking, maturity, or source. Yeast counts increased
\end{abstract}

\footnotetext{
Received May 10, 2011.

Accepted September 27, 2011.

${ }^{1}$ Current address: Department of Animal Science (Institute of Agricultural and Life Science), Gyeongsang National University, Jinju 660-701, South Korea.

${ }^{2}$ Current address: Faculty of Medical Sciences, Anton de Kom University of Suriname, Paramaribo, Suriname.

${ }^{3}$ Corresponding author: adesogan@ufl.edu
}

with maturity and exceeded $10^{5} \mathrm{cfu} / \mathrm{g}$; therefore, all silages deteriorated with $26 \mathrm{~h}$, irrespective of treatment. Among the hybrids examined, the optimal maturity for optimizing DM yield and nutritive value of the ASG and HSG hybrids was 37\% DM. Stay-green ranking had maturity-dependent effects on the yield of hybrids but had varying effects on nutritional value depending on the source of the hybrid.

Key words: corn, maturity, stay-green, nutritive value

\section{INTRODUCTION}

Florida dairy producers have been concerned about a possible link between reduced milk yield, digestive upsets, and hemorrhagic bowel syndrome in cattle consuming corn silage with high stay-green (SG) rankings. This study aimed to understand the effects of hybrid SG ranking on the quality of corn forage and silage, and the companion study examined hybrid SG ranking effects on the performance of dairy cows (Arriola et al., 2012). Bekavac et al. (1998) defined SG hybrids as those in which the green plant tissue area is above the population average and the grain moisture concentration is lower than or equal to the population average. Stay-green is used as an indicator of reduced plant lodging and increased disease and pest resistance (Thomas and Smart, 1993), good plant health later in the season (Crosbie, 1982), reduced progressive senescence, and tolerance to postflowering drought (Rosenow and Clark, 1981). The trait has been associated with greater water and chlorophyll concentration in the leaves at "stover" maturity, and high stalk and leaf moisture concentrations (Thomas and Smart, 1993; Bekavac et al., 1998). Thomas and Smart (1993) noted that different types of SG exist. The first includes functionally stay-green hybrids that photosynthesize longer than normal due to alteration of genes involved in the onset and regulation of senescence. The second type of SG is cosmetic because the plants are green but lack photosynthetic competence. Many current silage hybrids have high SG rankings but it is unclear whether they belong to the former or latter group because no standard method of assigning SG rankings to commercial hybrids exists. 
Most of the desirable attributes of SG hybrids occur late in the growing season, typically beyond the black layer stage. Therefore, the characteristic is more important for grain production than for silage production. The associated asynchronous dry-down rates of the ear and stover can result in drier kernels and wetter stalks and leaves because the ears mature faster than the stover. Consequently, kernel milk lines of SG hybrids are more advanced relative to whole-plant maturity such that the traditional relationship between whole-plant silage moisture concentration and kernel milk line no longer holds for SG hybrids (Lauer, 1998). Harvesting SG hybrids at the traditionally recommended kernel milk line stages (Wiersma et al., 1993) can result in excess moisture concentrations in the forage, which may explain increased instances of seepage from silos (Lauer, 1998). Excess moisture could also predispose ensiled forage to clostridial fermentations if the $\mathrm{pH}$ decreases slowly, to seepage and attendant losses of soluble nutrients and eutrophication of nearby water bodies, and to increased proteolysis and worsened fermentation (Kim and Adesogan, 2006). The foregoing emphasizes the importance of basing timing of harvests on measured whole-plant moisture concentration rather than using plant indicators (Lauer, 1998). Prolonged harvest delays to allow the stalk to dry could predispose to increased grain hardness and silage porosity, reduced silage density, and growth of spoilage or pathogenic organisms during feedout. However, little is known about the effects of harvesting at different maturities on the nutritive value or ensiling characteristics of SG hybrids. In fact, relatively few studies exist on the yield potential and nutritional attributes of SG corn silage hybrids. One study suggested that yields did not differ between SG and conventional hybrids (Wilkinson and Hill, 2003). Others associated the SG characteristic with lower digestibility (Ettle and Schwarz, 2003; Meisser and Weiss, 2003) and some indicated that milk yield did not differ between dairy cows fed SG hybrids and those fed with synchronous drying of the ear and stover hybrids (dry-down hybrids; Ettle and Schwarz, 2003; Zorn et al., 2008). The objective of this study was to determine the effect of maturity at harvest, SG ranking, and hybrid source on the nutritive value of the whole plant and plant fractions of hybrids with different SG rankings. A second objective was to determine how maturity, SG ranking, and hybrid source affect the fermentation and aerobic stability of corn silages.

\section{MATERIALS AND METHODS}

\section{Planting and Establishment}

Two corn hybrids with high SG (HSG) rankings, Pioneer 31 Y43 (Pioneer Hi-Bred International, Des
Moines, IA) and Croplan Genetics 827 (Croplan Genetics, St. Paul, MN) were compared with 2 near-isogenic varieties with average SG (ASG) rankings (Pioneer 32D99 and Croplan Genetics 799). Near-isogenic, low SG hybrids were not available for the study. The relative maturity of the hybrids was $117 \pm 0.8 \mathrm{~d}$ and the planting rate was 72,000 seeds/ha. Hybrids were grown on an irrigated field with a predominant soil type of Sparr sand (loamy, siliceous, hyperthermic Grossa-renic paleudult; $\mathrm{pH}$ 6.5) at the Plant Science Research and Education Center (Citra, FL). The planting area was divided into 4 blocks, and each block was subdivided into four $1-\times 6-\mathrm{m}$ plots. Each plot was randomly assigned to 1 of the 4 hybrids, resulting in 4 replications per treatment. Starter fertilizer was applied at a rate of $16-5-22 \mathrm{~kg} / \mathrm{ha}\left(\mathrm{N}-\mathrm{P}_{2} \mathrm{O}_{5}-\mathrm{K}_{2} \mathrm{O}\right)$ at planting based on soil test followed by split applications at the rate of 2060-211 kg/ha during the growth of the plant. Ambient temperature during the growth period ranged from 20.5 to $33.4^{\circ} \mathrm{C}$.

\section{Harvesting and Ensiling}

Timing of harvest was estimated based on DM concentrations of representatively sampled, chopped corn plants from at least 2 plots per variety. On the day of harvest, corn plants within a $1-\times 2-\mathrm{m}$ area of each plot were harvested at 25 (maturity 1), 32 (maturity 2), and $37 \%$ (maturity 3) DM with a one-row forage harvester at a cutting height of $20 \mathrm{~cm}$. The harvested forage from each plot was divided into thirds for chemical analysis of separated botanical fractions (ear vs. stover), chemical analysis of the whole plant, and for ensiling. Each sample was chopped to lengths of approximately 2 $\mathrm{cm}$ and representatively subsampled $(0.2 \mathrm{~kg})$ for DM analysis $\left(105^{\circ} \mathrm{C}\right.$ for $\left.24 \mathrm{~h}\right)$. Representative samples $(8$ $\mathrm{kg}$ ) of the herbage reserved for ensiling were placed in polythene bags within quadruplicate $20-\mathrm{L}$ mini-silos (one plot per silo) and sealed within $2 \mathrm{~h}$ of harvest. Silos were stored for $107 \mathrm{~d}$ at ambient temperature $\left(25^{\circ} \mathrm{C}\right)$ in a covered barn.

\section{Chemical Analysis}

Dried whole-plant, stover, and ear samples were ground to pass through a 1-mm screen in a Wiley Mill (A. H. Thomas, Philadelphia, PA). Ash concentration was determined in a muffle furnace at $550^{\circ} \mathrm{C}$ for $6 \mathrm{~h}$. Starch was determined using the procedure of Holm et al. (1986). The anthrone reaction assay (Ministry of Agriculture, Fisheries and Food, 1986) was used to quantify water-soluble carbohydrates (WSC). Concentration of total $\mathrm{N}$ was determined by rapid combustion using a macro-elemental $\mathrm{N}$ analyzer (Vario MAX CN, 
25.00-5003, Hanau, Germany) and used to compute $\mathrm{CP}$ concentrations $(\mathrm{CP}=\mathrm{N} \times 6.25)$. Concentrations of NDF and ADF were determined using an Ankom Fiber Analyzer (Ankom Technology, Macedon, NY) and the method of Van Soest et al. (1991). An amylase pretreatment step was included in the NDF analysis. In vitro apparent DM digestibility (IVDMD) was measured using an adaptation of the Tilley and Terry (1963) procedure for Ankom Daisy II Incubators (Ankom Technology).

For ensiled forage samples, final silo weights were recorded at silo opening, and silages from each treatment were subsampled for DM determination (450 g), silage juice extraction $(20 \mathrm{~g})$, microbial analysis (400 $\mathrm{g}$ ), chemical analysis (800 g), and aerobic stability (1 $\mathrm{kg}$ ). Samples destined for microbial analyses (yeast and mold counts) were placed in an icebox and dispatched the same day to the American Bacteriological and Chemical Research Corporation (Gainesville, FL). Yeasts and molds were enumerated after spread plating on malt extract agar and incubation for $5 \mathrm{~d}$ at $25^{\circ} \mathrm{C}$. Aerobic stability was measured by placing thermocouple wires at the center of a bag containing $1 \mathrm{~kg}$ of silage within an open-top polystyrene box. The silages were covered with 2 layers of cheesecloth to prevent drying. The thermocouple wires were connected to data loggers (Campbell Scientific Inc., North Logan, UT) that recorded silage and ambient temperature every 30 min for $5 \mathrm{~d}$. Aerobic stability was denoted by the hours that elapsed before a $2^{\circ} \mathrm{C}$ increase in silage temperature above ambient temperature $\left(23^{\circ} \mathrm{C}\right)$. Silage DM concentration was determined at $60^{\circ} \mathrm{C}$ in a forced air oven for $48 \mathrm{~h}$. Ash concentration was determined in a muffle furnace at $550^{\circ} \mathrm{C}$ for $6 \mathrm{~h}$. Silage juice was obtained by blending $20 \mathrm{~g}$ of silage with $200 \mathrm{~mL}$ of distilled water for $30 \mathrm{~s}$ at high speed and filtering the slurry through 2 layers of cheesecloth. The $\mathrm{pH}$ was measured at opening with an electrode (Accumet model HP-71, Fisher Scientific, Pittsburgh, PA). The filtrate was centrifuged at $4^{\circ} \mathrm{C}$ and $21,500 \times g$ for 20 min and the supernatant was frozen $\left(-20^{\circ} \mathrm{C}\right)$ in $20-\mathrm{mL}$ vials for subsequent analysis of VFA and $\mathrm{NH}_{3}-\mathrm{N}$. Organic acids were measured using the method of Muck and Dickerson (1988) and an HPLC system (Hitachi, FL 7485, Tokyo, Japan) coupled to a UV detector (Spectroflow 757, ABI Analytical Kratos Division, Ramsey, NJ) set at $210 \mathrm{~nm}$. Ammonia-N was determined using an adaptation for the Technicon auto analyzer (Technicon, Tarrytown, NY) of the Noel and Hambleton (1976) procedure that involved colorimetric $\mathrm{N}$ quantification. Dried silage samples were ground (1mm screen) and analyzed for WSC, starch, CP, NDF, $\mathrm{ADF}$, and IVDMD using the same procedures used for dried unensiled plant fractions.

\section{Statistical Analysis}

The experimental design was a split plot in which the whole plot was source $\times$ SG ranking and the subplot was maturity at harvest. The data were analyzed using the GLM procedure of SAS (version 9, SAS Institute Inc., Cary, NC) and reported as least squares means. The model included SG, maturity, hybrid source (company), and all interactions of these terms. Whole-plant, ear, and stover data were separately analyzed, and fresh samples were separately analyzed from ensiled samples. Polynomial contrasts were used to test the effect of maturity $(25,32$, and $37 \% \mathrm{DM})$ on nutritive value and yield. The coefficients for the contrasts were generated with the IML procedure of SAS. Significance was declared at $P<0.05$. Data that were more than 2 standard deviations from the mean were considered outliers and excluded from the statistical analyses to ensure outliers did not contribute to the results.

\section{RESULTS AND DISCUSSION}

\section{Yield and Chemical Composition of the Unensiled Whole Plant}

All statements about differences in the hybrids from the 2 companies relate to the performance of the hybrids under the test conditions and may not reflect differences between the tested hybrids under different growth conditions. Yield of DM increased linearly $(P=$ $0.006)$ with increasing maturity and was greater $(P=$ 0.001) for Pioneer hybrids compared with Croplan hybrids (Table 1). However, maturity effects on yield were influenced by SG ranking $(P=0.06)$. The HSG hybrids had greater DM yield than ASG hybrids at maturity 1 (16.1 vs. $15.1 \mathrm{t}$ of $\mathrm{DM} / \mathrm{ha}$ ) and 3 (20.2 vs. $17.0 \mathrm{t}$ of $\mathrm{DM} / \mathrm{ha}$ ) but not at maturity 2 (14.6 vs. $16.1 \mathrm{t}$ of DM/ ha). The increased yield with higher SG rankings at maturity 1 and 3 may have been due to increased photosynthesis (Thomas and Smart, 1993) but it is unclear why the response was absent at maturity 2 . Wilkinson and Hill (2003) reported similar yields of conventional and SG corn hybrids harvested at 26 to $44 \%$ DM. Their results may have differed from those in this study because of differences in genotype and growth conditions.

Whole-plant DM and starch concentrations increased linearly $(P<0.001)$ with maturity, whereas $\mathrm{CP}, \mathrm{NDF}$, and ADF concentrations decreased linearly $(P<0.001)$ at rates that depended on the source $(P \leq 0.07)$. These changes reflect the transition from vegetative to reproductive growth in the plants. Ash concentration changed quadratically with maturity at rates that differed with source $(P=0.05)$. Changes in WSC concentration with 
Table 1. Yield and chemical composition of unensiled whole plants ${ }^{1}$ from corn hybrids differing in stay-green (SG) ranking, maturity (m), and source (s)

\begin{tabular}{|c|c|c|c|c|c|c|c|c|c|c|c|c|c|}
\hline \multirow[b]{2}{*}{ Item } & \multirow[b]{2}{*}{ Maturity $^{2}$} & \multicolumn{2}{|c|}{ High SG } & \multicolumn{2}{|c|}{ Average SG } & \multirow[b]{2}{*}{$\mathrm{SE}$} & \multicolumn{7}{|c|}{$P$-value ${ }^{3}$} \\
\hline & & PN31Y43 & CPL827 & PN32D99 & CPL799 & & $\mathrm{SG}$ & Maturity & Source & $\mathrm{SG} \times \mathrm{m}$ & $\mathrm{SG} \times \mathrm{s}$ & $\mathrm{m} \times \mathrm{s}$ & $\begin{array}{l}\mathrm{SG} \times \\
\mathrm{m} \times \mathrm{s}\end{array}$ \\
\hline \multirow[t]{3}{*}{ Yield, t of DM/ha } & 1 & 17.1 & 15.1 & 15.9 & 14.2 & \multirow[t]{3}{*}{1.7} & \multirow[t]{3}{*}{ NS } & \multirow[t]{3}{*}{$0.006, \mathrm{~L}, \mathrm{Q}$} & \multirow[t]{3}{*}{0.001} & \multirow[t]{3}{*}{0.06} & \multirow[t]{2}{*}{ NS } & \multirow[t]{3}{*}{ NS } & \multirow[t]{3}{*}{ NS } \\
\hline & 2 & 16.3 & 12.9 & 17.8 & 14.4 & & & & & & & & \\
\hline & 3 & 22.9 & 17.7 & 18.4 & 15.6 & & & & & & & & \\
\hline \multirow[t]{3}{*}{$\mathrm{DM}, \%$} & 1 & 26.7 & 22.0 & 25.8 & 26.5 & \multirow[t]{3}{*}{1.83} & \multirow[t]{3}{*}{ NS } & \multirow[t]{3}{*}{$<0.001, \mathrm{~L}$} & \multirow[t]{3}{*}{ NS } & \multirow[t]{3}{*}{ NS } & \multirow[t]{3}{*}{0.05} & \multirow[t]{3}{*}{0.01} & \multirow[t]{3}{*}{ NS } \\
\hline & 2 & 30.6 & 32.8 & 29.0 & 35.2 & & & & & & & & \\
\hline & 3 & 38.4 & 34.8 & 38.3 & 37.4 & & & & & & & & \\
\hline Ash, $\%$ of DM & 1 & 3.3 & 3.2 & 3.5 & 3.7 & 0.24 & NS & $0.009, \mathrm{Q}$ & 0.01 & NS & NS & 0.05 & NS \\
\hline & 2 & 2.8 & 2.9 & 2.8 & 2.9 & & & & & & & & \\
\hline & 3 & 2.9 & 4.1 & 2.9 & 3.4 & & & & & & & & \\
\hline Starch, \% of DM & 1 & 17.5 & 14.7 & 16.0 & 20.6 & 1.97 & NS & $<0.001, \mathrm{~L}$ & NS & NS & 0.001 & 0.001 & NS \\
\hline & 2 & 27.5 & 27.6 & 24.4 & 35.5 & & & & & & & & \\
\hline & 3 & 34.7 & 23.7 & 27.9 & 29.7 & & & & & & & & \\
\hline $\mathrm{WSC},{ }^{4} \%$ of $\mathrm{DM}$ & 1 & 9.1 & 10.1 & 9.1 & 12.7 & 0.89 & 0.003 & NS & NS & NS & 0.08 & 0.001 & 0.03 \\
\hline & 2 & 11.6 & 9.1 & 13.6 & 8.6 & & & & & & & & \\
\hline & 3 & 8.4 & 7.5 & 8.7 & 13.0 & & & & & & & & \\
\hline $\mathrm{CP}, \%$ of $\mathrm{DM}$ & 1 & 9.9 & 9.2 & 9.5 & 9.4 & 0.67 & NS & $0.001, \mathrm{~L}$ & NS & NS & NS & NS & NS \\
\hline & 2 & 8.6 & 8.6 & 8.2 & 8.1 & & & & & & & & \\
\hline & 3 & 8.3 & 6.6 & 7.5 & 7.9 & & & & & & & & \\
\hline $\mathrm{NDF}, \%$ of DM & 1 & 56.9 & 60.8 & 59.0 & 53.0 & 1.85 & 0.002 & $<0.001, \mathrm{~L}$ & NS & NS & $<0.001$ & 0.02 & NS \\
\hline & 2 & 46.3 & 48.5 & 48.4 & 39.2 & & & & & & & & \\
\hline & 3 & 43.7 & 56.1 & 47.4 & 43.5 & & & & & & & & \\
\hline $\mathrm{ADF}, \%$ of $\mathrm{DM}$ & 1 & 30.5 & 31.8 & 31.8 & 27.1 & 1.51 & 0.008 & $<0.001, \mathrm{~L}$ & NS & NS & 0.001 & 0.07 & NS \\
\hline & 2 & 25.5 & 24.9 & 24.8 & 20.0 & & & & & & & & \\
\hline & 3 & 21.9 & 29.2 & 24.5 & 22.1 & & & & & & & & \\
\hline IVDMD,${ }^{5} \%$ of DM & 1 & 62.1 & 59.2 & 61.3 & 63.0 & 1.72 & 0.004 & $0.04, \mathrm{Q}$ & 0.009 & NS & $<0.001$ & NS & NS \\
\hline & 2 & 64.5 & 59.3 & 64.1 & 66.9 & & & & & & & & \\
\hline & 3 & 65.2 & 55.3 & 62.4 & 62.5 & & & & & & & & \\
\hline Yield, t of digestible DM/ha & 1 & 10.53 & 9.30 & 10.23 & 9.43 & 0.9 & NS & 0.09 & $<0.001$ & NS & NS & NS & NS \\
\hline & 2 & 10.48 & 8.71 & 11.14 & 8.93 & & & & & & & & \\
\hline & 3 & 14.25 & 9.74 & 10.87 & 9.30 & & & & & & & & \\
\hline${ }^{1}$ Source: PN from Pioneer Hi- & d Interna & al (Des I & nes, IA) & CPL from $\mathrm{C}$ & roplan Ge & etics ( & Paul, & & & & & & \\
\hline${ }^{M}$ Maturity 1,2 , and $3=25,3$ & d $37 \% \mathrm{D}$ & at harvest & respective & & & & & & & & & & \\
\hline${ }^{3} \mathrm{NS}=$ not significant, $P>0$. & $\mathrm{L}=$ linear & effect, $P<$ & $.05 ; \mathrm{Q}=\mathrm{c}$ & Iratic effect, & $P<0.05$ & & & & & & & & \\
\hline${ }^{4} \mathrm{WSC}=$ water-soluble carbol & rate. & & & & & & & & & & & & \\
\hline${ }^{5} \mathrm{IVDMD}=$ in vitro $\mathrm{DM}$ diges & ility. & & & & & & & & & & & & \\
\hline
\end{tabular}


maturity depended on source and SG ranking $(P=$ 0.03). Whole-plant DM, ash, starch, and CP concentrations were unaffected by SG ranking

Unlike Croplan Genetics hybrids, Pioneer HSG hybrids had greater DM and starch concentrations and IVDMD and lower concentrations of ADF and NDF than their ASG hybrids $(\mathrm{SG} \times$ source interaction; $P$ $<0.05)$. This indicates that the SG effect on nutritive value depends on the source of the hybrid, perhaps because criteria used for assigning SG rankings are not consistent across hybrid companies. Subedi and Ma (2005) reported that a leafy hybrid had a greater whole-plant DM concentration than an SG hybrid, but Wilkinson and Hill (2003) reported that whole-plant DM concentration was similar between SG and conventional cultivars. Subedi and Ma (2005) also reported that $\mathrm{CP}$ concentration did not differ for leafy and SG hybrids.

Increasing SG ranking increased the IVDMD of Pioneer hybrids but decreased those of Croplan hybrids. This further indicates that effects of SG depended on the source of the hybrids. Published results on effects of SG on digestibility are equivocal. Some studies associated SG hybrids with lower digestibility values than conventional or lower SG hybrids (Meisser and Weiss, 2003; Arriola et al., 2012), but others associated SG stover, but not the whole plant, with greater digestibility (Hartmann et al., 2000; Schlagheck et al., 2000). These differences emphasize the need for more studies on differences in SG rankings of hybrids and their effects on forage quality.

The IVDMD $(P=0.04)$ increased in a quadratic manner with maturity and the greatest values occurred at maturity 2 in most cases. Digestible DM yields were greater for Pioneer hybrids, and values for both hybrids tended $(P=0.09)$ to increase with maturity, suggesting that hybrids with average to high SG rankings should be harvested at about 37\% DM. This agrees with the results of a study aimed at determining the optimal maturity for harvesting SG corn hybrids (Hartmann and Geiger, 2001). The study compared 20 cultivars harvested at 30 to 31,33 to 34 , and 37 to $39 \% \mathrm{DM}$ at 6 sites and reported that the optimum maturity at harvest for low SG (early maturing) hybrids was 33 to $34 \%$ DM, whereas it was 37 to $39 \%$ DM for high SG (later maturing) hybrids. The results of the current and latter studies suggest that SG hybrids should be harvested at the upper end of the recommended range (30 to 40\% DM; Lauer, 1998; Darby and Lauer, 2002) for corn silage. Harvesting average to high SG hybrids at relatively higher DM concentrations would also reduce the risk that excess moisture in the stover would adversely affect the fermentation.

\section{Chemical Composition of the Stover}

The stover of HSG hybrids had less $(P=0.02)$ DM than those of ASG hybrids (25.8 vs. $23.9 \%$ ) but the difference tended to be more pronounced among Croplan hybrids $(\mathrm{SG} \times$ source interaction, $P=0.09$; Table 2$)$. Likewise, several studies have shown that stover of SG hybrids had greater moisture concentration than that of non-SG hybrids (Schlagheck et al., 2000; Schwarz and Ettle, 2000; Subedi and Ma, 2005) but one study did not (Cone et al., 2008). Greater stover moisture concentrations are expected for SG hybrids because of the high correlation between the SG trait and leaf and stalk moisture concentrations in corn hybrids (Bekavac et al., 1998).

The stover of Pioneer HSG hybrids had greater WSC concentrations than those of their ASG hybrids but a contrasting trend was evident among Croplan hybrids $(\mathrm{SG} \times$ maturity interaction; $P=0.01)$. The stover of HSG hybrids from both sources had greater $(P=0.02)$ CP concentrations than ASG hybrids (8.6 vs. $7.4 \%$ of $\mathrm{DM}$ ), but the difference tended to be more pronounced for Croplan hybrids than for Pioneer hybrids $(\mathrm{SG} \times$ maturity interaction; $P=0.07$ ). These results may be due to greater proportion of chlorophyll-protein complexes in hybrids with higher SG rankings (Borrell et al., 2001) because of the greater green leaf proportion (Bekavac et al., 1998). Subedi and Ma (2005) also reported that an SG hybrid had greater leaf $\mathrm{N}$ concentration than a non-SG hybrid and attributed the difference to a longer duration of $\mathrm{N}$ uptake in SG hybrids.

Unlike that of Pioneer hybrids, the stover of Croplan HSG hybrids tended to have greater NDF $(P<0.001)$ and $\operatorname{ADF}(P=0.005)$ concentrations and lower IVDMD $(P=0.002)$ than Croplan ASG hybrids $(\mathrm{SG} \times$ source interaction, $P<0.05$ ). These results are consistent with those obtained from the corresponding whole plants. The stover of Croplan hybrids had greater $(P=0.02)$ ash concentration (5.2 vs. $4.5 \%$ of DM) than those of Pioneer hybrids, and stover DM and ash concentrations increased linearly $(P=0.01$ and 0.06$)$ with maturity. Concentrations of stover CP $(P=0.001)$ and IVDMD $(P<0.001)$ decreased linearly with maturity, whereas concentrations of WSC, NDF, and ADF were unaffected. Decreases in IVDMD with maturity were likely due to increasing lignification.

\section{Chemical Composition of the Ear}

In agreement with Wilkinson and Hill (2003) and Ettle and Schwarz (2003), ear WSC concentration decreased linearly $(P<0.001)$ with increasing maturity, whereas DM concentration increased linearly $(P$ 
Table 2. Chemical composition of unensiled stovers from corn hybrids ${ }^{1}$ differing in stay-green (SG) ranking, maturity (m), and source (s)

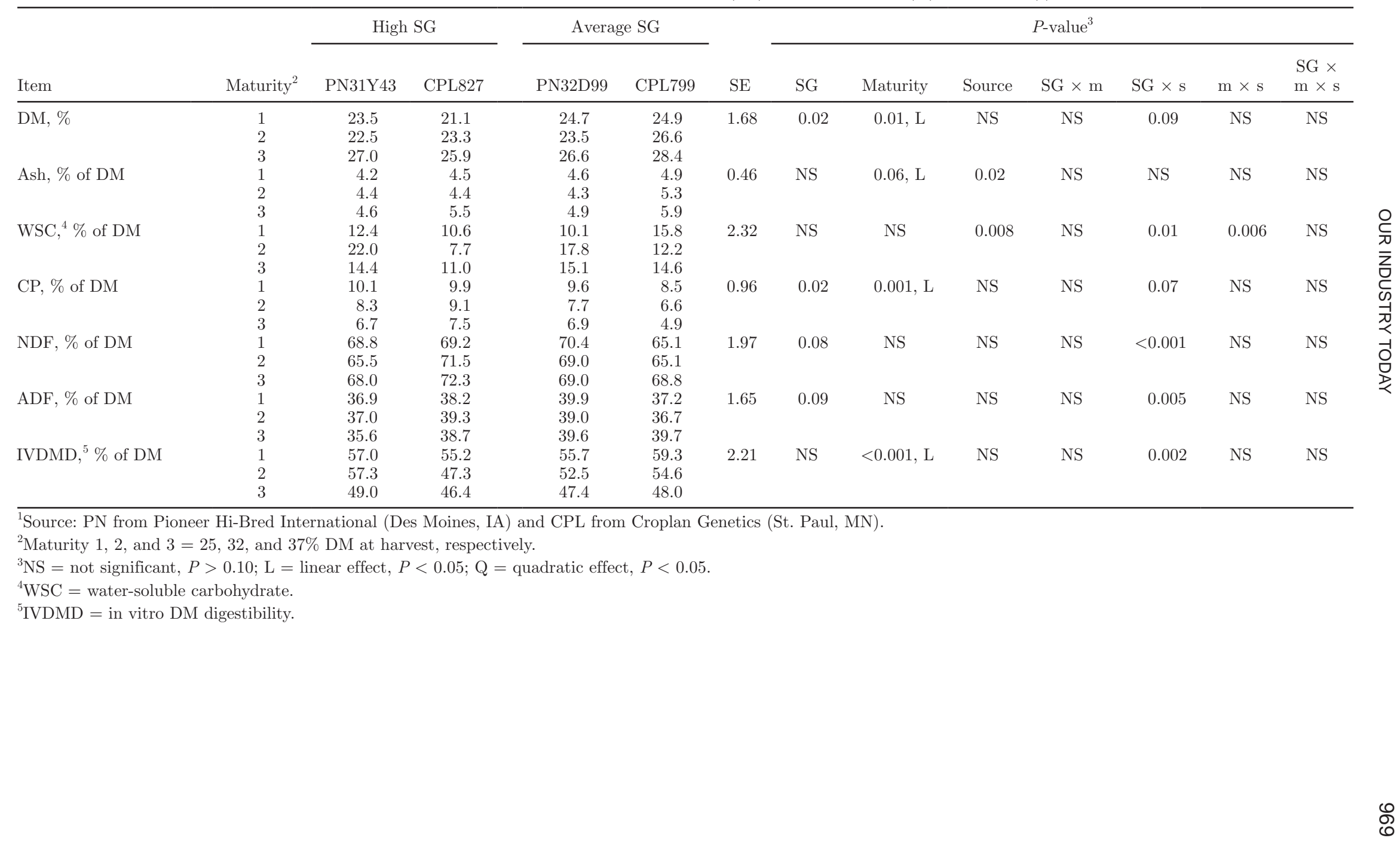


$<0.001$; Table 3). Pioneer HSG hybrids had greater $\mathrm{DM}$ and $\mathrm{CP}$ concentrations in the ear than their ASG hybrids but an opposite trend occurred among Croplan hybrids $(\mathrm{SG} \times$ source interaction, $P<0.05$; Table $3)$. Therefore, the characteristic greater ear moisture concentration of SG versus non-SG hybrids (Ettle and Schwarz, 2003; Wilkinson and Hill, 2003) was only evident among Croplan hybrids. High SG hybrids also had greater $(P<0.01)$ ear ash concentration than ASG hybrids (2.0 vs. $1.8 \%$ of DM). Ear starch concentration was unaffected by source or SG ranking but increased with maturity in a quadratic manner as expected.

\section{Chemical Composition of the Silage}

As reported by Ettle and Schwarz (2003), who compared SG hybrids versus hybrids with synchronous ear and stover drying rates (dry down hybrids), Croplan HSG hybrids had lower DM and starch concentrations and tended to have greater NDF and ADF concentrations than their ASG hybrids but contrasting trends were evident among Pioneer HSG $(\mathrm{SG} \times$ source interaction, $P<0.05$; Table 4). Consequently, and as in the unensiled whole plant and stover, the IVDMD of ensiled HSG hybrids from Croplan Genetics tended to be lower than those of their ASG hybrids, but this trend was not detected among Pioneer hybrids (SG $\times$ source interaction; $P=0.07)$. Ettle and Schwarz (2003) noted that a dry-down hybrid had greater IVDMD than an SG hybrid, and Meisser and Weiss (2003) reported lower digestibility values for SG versus non-SG hybrids. In contrast, Havilah and Kaiser (1994) reported similar digestibility results for SG and non-SG hybrids. These discrepancies emphasize that generalizations about effects of the SG characteristic may be misleading and highlight the need for more research to differentiate between SG characteristics of commercial silage hybrids.

Residual WSC concentration was greater $(P<0.05)$ in HSG (0.71 vs. $0.64 \%$ of DM) than ASG hybrids, and $\mathrm{CP}$ concentration tended to be greater $(P=0.08)$ in HSG than ASG hybrids (9.6 vs. $9.0 \%$ of DM). The latter reflects the higher $\mathrm{CP}$ concentration of the HSG stover and agrees with reported higher leaf $\mathrm{N}$ concentrations in SG versus non-SG sorghum hybrids (Borrell and Hammer, 2000).

Dry matter and starch concentrations increased linearly $(P<0.001)$ with increasing maturity, whereas WSC, CP, NDF, and ADF concentrations decreased linearly $(P<0.001)$, but maturity did not affect IVDMD. Others have also noted that IVDMD and in situ degradability of corn silage remained unchanged within the range of maturities examined in this study and attributed this to transition from vegetative to reproductive growth (Bal et al., 2002).

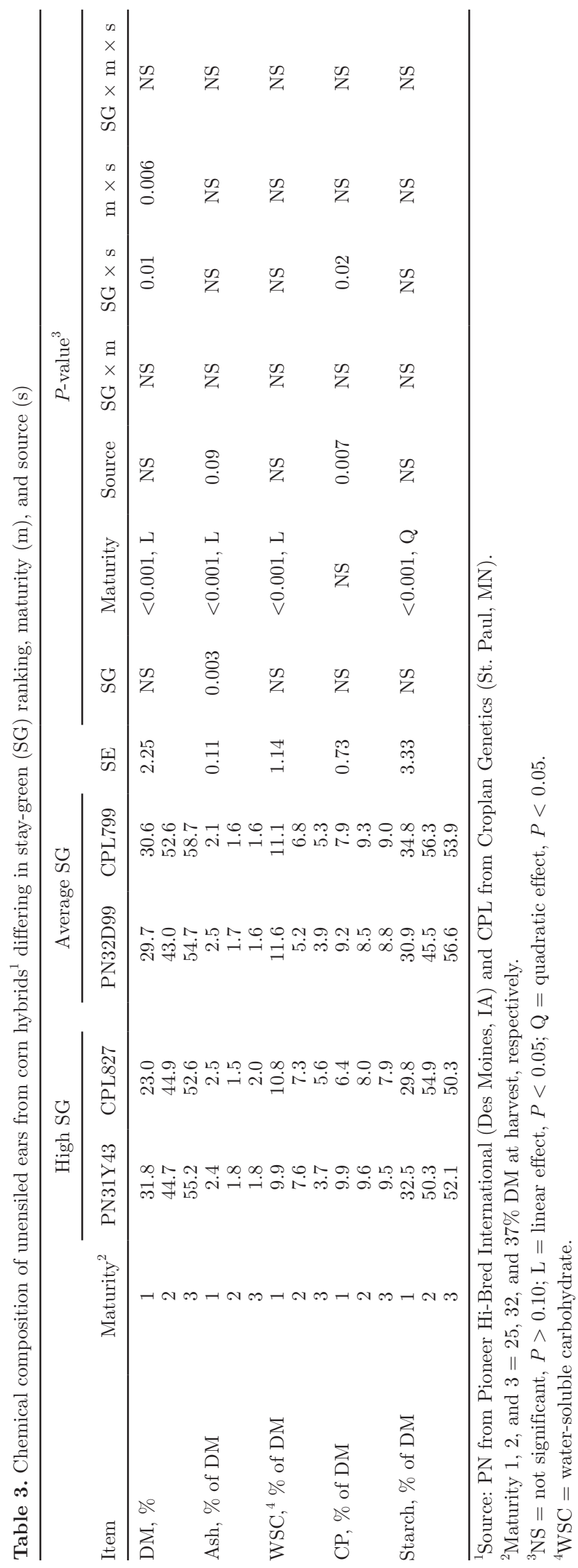


Table 4. Chemical composition of corn silages made from hybrids ${ }^{1}$ differing in stay-green (SG) ranking, maturity (m), and source (s)

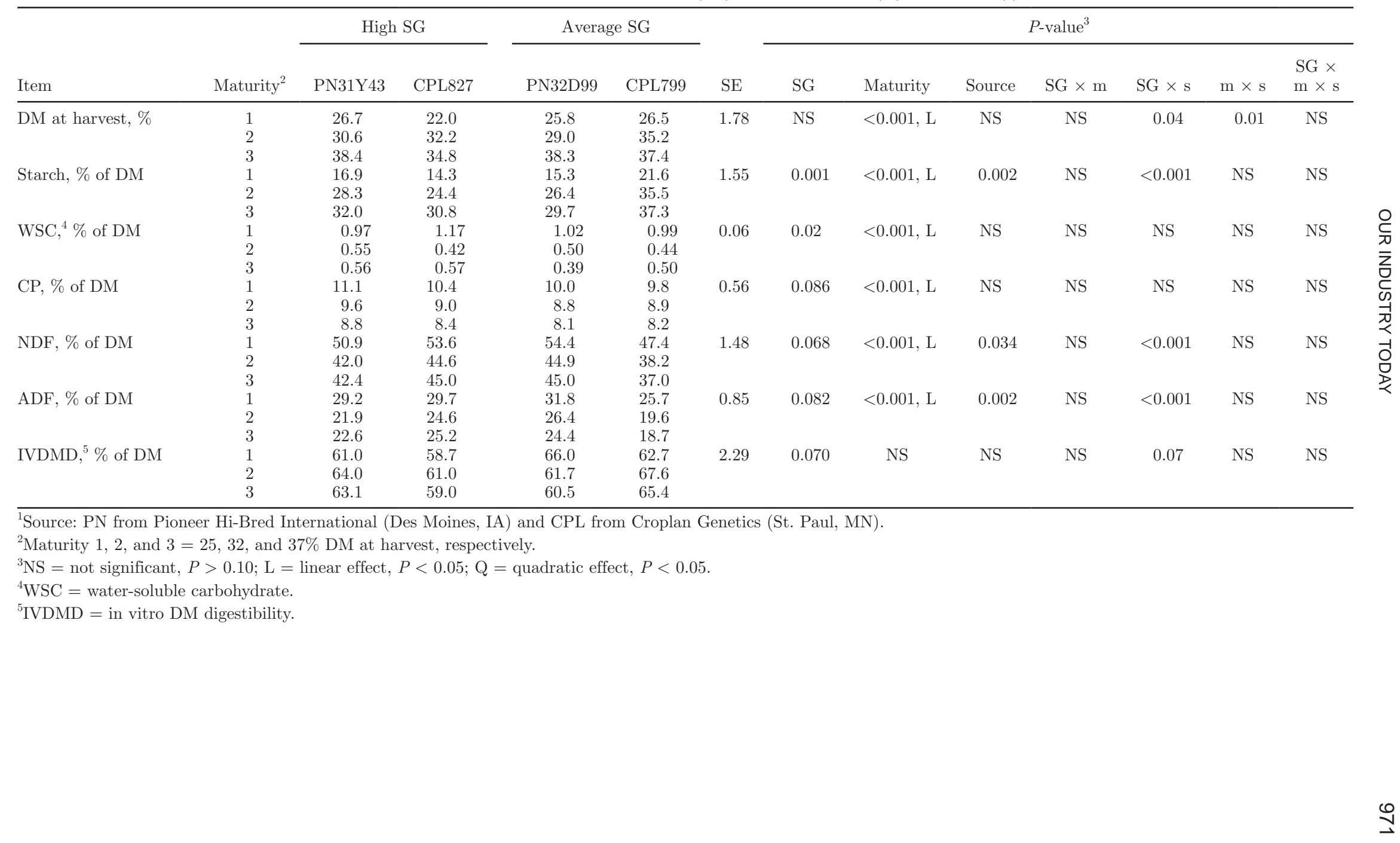


Table 5. Fermentation indices, fungal counts, and aerobic stability of corn silages made from hybrids ${ }^{1}$ differing in stay-green (SG) ranking, maturity (m), and source (s)

\begin{tabular}{|c|c|c|c|c|c|c|c|c|c|c|c|c|c|}
\hline \multirow[b]{2}{*}{ Item } & \multirow[b]{2}{*}{ Maturity $^{2}$} & \multicolumn{2}{|c|}{ High SG } & \multicolumn{2}{|c|}{ Average SG } & \multirow[b]{2}{*}{$\mathrm{SE}$} & \multicolumn{7}{|c|}{$P$-value ${ }^{3}$} \\
\hline & & PN31Y43 & CPL827 & PN32D99 & CPL799 & & SG & Maturity & Source & $\mathrm{SG} \times \mathrm{m}$ & $\mathrm{SG} \times \mathrm{s}$ & $\mathrm{m} \times \mathrm{s}$ & $\begin{array}{l}\mathrm{SG} \times \\
\mathrm{m} \times \mathrm{s}\end{array}$ \\
\hline \multirow[t]{3}{*}{$\mathrm{pH}$} & 1 & 3.8 & 3.7 & 3.7 & 3.7 & \multirow[t]{3}{*}{0.03} & \multirow[t]{3}{*}{0.09} & \multirow[t]{3}{*}{$0.003, \mathrm{~L}$} & \multirow[t]{3}{*}{ NS } & \multirow[t]{3}{*}{ NS } & \multirow[t]{3}{*}{0.02} & \multirow[t]{3}{*}{ NS } & \multirow[t]{3}{*}{ NS } \\
\hline & 2 & 3.8 & 3.8 & 3.7 & 3.8 & & & & & & & & \\
\hline & 3 & 3.8 & 3.7 & 3.8 & 3.8 & & & & & & & & \\
\hline \multirow{3}{*}{$\mathrm{NH}_{3}-\mathrm{N}, \%$ of total $\mathrm{N}$} & 1 & 14.2 & 11.8 & 13.7 & 15.2 & \multirow[t]{3}{*}{0.87} & \multirow[t]{3}{*}{ NS } & \multirow[t]{3}{*}{$0.02, \mathrm{Q}$} & \multirow[t]{3}{*}{ NS } & \multirow[t]{3}{*}{ NS } & \multirow[t]{3}{*}{ NS } & \multirow[t]{3}{*}{ NS } & \multirow[t]{3}{*}{0.03} \\
\hline & 2 & 13.1 & 10.9 & 10.8 & 11.7 & & & & & & & & \\
\hline & 3 & 12.6 & 12.2 & 14.0 & 11.2 & & & & & & & & \\
\hline \multirow[t]{3}{*}{ Lactic acid, $\%$ of DM } & 1 & 7.65 & 7.31 & 6.37 & 8.65 & \multirow[t]{3}{*}{0.77} & \multirow[t]{3}{*}{ NS } & \multirow[t]{3}{*}{$<0.001, \mathrm{~L}$} & \multirow[t]{3}{*}{ NS } & NS & NS & NS & NS \\
\hline & 2 & 5.84 & 4.62 & 5.65 & 5.08 & & & & & & & & \\
\hline & 3 & 4.30 & 4.70 & 5.68 & 4.59 & & & & & & & & \\
\hline Acetic acid, $\%$ of DM & 1 & 4.49 & 4.31 & 3.91 & 5.12 & 0.47 & NS & $<0.001, \mathrm{~L}$ & NS & NS & NS & NS & NS \\
\hline & 2 & 3.09 & 2.44 & 2.83 & 2.55 & & & & & & & & \\
\hline & 3 & 2.26 & 2.45 & 3.09 & 2.88 & & & & & & & & \\
\hline Propionic acid, $\%$ of DM & 1 & 1.26 & 0.58 & 0.78 & 1.34 & 0.19 & NS & $0.008, \mathrm{~L}$ & NS & NS & NS & NS & 0.04 \\
\hline & 2 & 1.12 & 0.77 & 0.91 & 0.70 & & & & & & & & \\
\hline & 3 & 0.74 & 0.57 & 0.83 & 0.31 & & & & & & & & \\
\hline Molds, log cfu/g & 1 & 3.27 & 3.27 & 3.20 & 3.39 & 0.3 & NS & $<0.001, \mathrm{~L}$ & NS & NS & NS & NS & 0.008 \\
\hline & 2 & 2.25 & 2.68 & 3.23 & 2.25 & & & & & & & & \\
\hline & 3 & 3.02 & 2.25 & 2.25 & 2.25 & & & & & & & & \\
\hline Yeasts, log cfu/g & 1 & 4.61 & 5.88 & 7.04 & 6.76 & 0.4 & $<0.001$ & $0.001, \mathrm{~L}$ & NS & 0.03 & NS & 0.03 & 0.004 \\
\hline & 2 & 5.97 & 4.54 & 7.18 & 6.66 & & & & & & & & \\
\hline & 3 & 8.12 & 6.11 & 7.11 & 7.68 & & & & & & & & \\
\hline Aerobic stability, h & 1 & 24.5 & 24.9 & 24.9 & 24.3 & 0.5 & NS & NS & NS & NS & NS & NS & NS \\
\hline & 2 & 24.4 & 25.6 & 25.1 & 24.0 & & & & & & & & \\
\hline & 3 & 24.1 & 24.1 & 25.1 & 25.0 & & & & & & & & \\
\hline
\end{tabular}

${ }_{1}^{1}$ Source: PN from Pioneer Hi-Bred International (Des Moines, IA) and CPL from Croplan Genetics (St. Paul, MN).

${ }^{2}$ Maturity 1,2 , and $3=25,32$, and $37 \% \mathrm{DM}$ at harvest, respectively.

${ }^{3} \mathrm{NS}=$ not significant, $P>0.10 ; \mathrm{L}=$ linear effect, $P<0.05 ; \mathrm{Q}=$ quadratic effect, $P<0.05$ 


\section{Fermentation Indices of the Silage}

On average, silage $\mathrm{pH}$ increased linearly $(3.72,3.77$, 3.77; $P<0.01)$ and ammonia-N concentration changed quadratically $(13.7,11.6,12.5 \%$ of total $\mathrm{N} ; P=0.02)$ with increasing maturity (Table 5 ). The $\mathrm{pH}$ response was due to linear $(P<0.001)$ decreases in concentrations of lactic and acetic acids with maturity. Similar results were reported by Neylon and Kung (2003), who attributed these responses to the combination of low WSC concentrations and reduction in growth of lactic acid bacteria because water activity decreased with increasing dryness as the forage matured. The greater acidity of the wetter, less mature silage in this study suggests that harvesting such corn for silage at immature stages could increase the chance of intake depression, particularly if acetic acid levels are as high as they were in this study. Propionic acid levels were also inexplicably high.

Ettle and Schwarz (2003) reported that dry-down and SG hybrids had similar $\mathrm{pH}$ but the dry-down hybrid had greater lactic acid concentration and lower acetic acid concentration than the SG hybrid. In this study, the Pioneer HSG hybrid had slightly less acidic $\mathrm{pH}$ than their ASG hybrid (3.80 vs. 3.73) but Croplan HSG and ASG hybrids had more similar values (3.73 vs. 3.77, $\mathrm{SG} \times$ source interaction; $P=0.02)$. Nevertheless, the $\mathrm{pH}$ values indicate that all silages were adequately fermented. Effects of SG ranking on concentrations of $\mathrm{NH}_{3}-\mathrm{N}$ and propionic acid differed with maturity $(P=$ 0.03 and 0.04 ) and source, but treatment effects were inconsistent. Source and SG ranking had no effect on concentrations of lactic and acetic acids. Butyric acid was not detected in the silages. Mold counts decreased linearly $(3.28,2.60,2.44 \mathrm{log} \mathrm{cfu} / \mathrm{g} ; P=0.001)$ with maturity, whereas yeast counts increased linearly (6.07, $6.08,7.23, P=0.001$; Table 5). However, both of these responses were dependent on source and SG ranking of hybrids $(\mathrm{SG} \times$ maturity $\times$ source interaction; $P<$ 0.01 ). Yeast counts may have increased with maturity because of decreasing concentrations of acetic acid, which is a potent antifungal agent (Moon, 1983), as well as lower dry packing density as the maturity increased. Although the differences in dry packing density across maturities may be considered a potentially confounding factor, this measure is now regarded as being less important than bulk or as-fed density because the latter accounts for silage porosity, whereas dry density does not (Holmes, 2009; Holmes and Muck, 2011). Because all forages were packed to the same bulk density, the treatments were not confounded by density. Mold counts were below the threshold $\left(10^{5} \mathrm{cfu} / \mathrm{g}\right)$ associated with aerobic spoilage (Pahlow and Zimmer, 1985; O'Kiely et al., 1987). However, counts of yeasts, which typically initiate aerobic spoilage, approached or exceeded the latter threshold. Therefore, all silages deteriorated within $26 \mathrm{~h}$ and aerobic stability was not affected by treatment. Wyss (2003) also reported that SG hybrids deteriorated as quickly as non-SG hybrids. Collectively, the results indicate that SG ranking and hybrid source had no major effects on their fermentation or aerobic stability. Cone et al. (2008) also reported no systematic differences in the quality of silage made from $\mathrm{SG}$ and dry-down hybrids. The notion that higher plant moisture concentrations in HSG hybrids would worsen the fermentation and predispose to clostridial proteolysis and butyric acid production was not supported among the ASG and HSG hybrids in this study.

\section{CONCLUSIONS}

Yields of whole-plant DM and digestible DM and concentrations of starch and DM increased or tended to increase with maturity, whereas NDF concentrations decreased. Based on these results, the optimal maturity for optimizing DM yield and nutritive value of the ASG and HSG hybrids was 37\% DM. Effects of increasing SG ranking on the moisture concentration and nutritive value differed with hybrid source. For instance, Croplan Genetics HSG hybrids had greater NDF and ADF and lower IVDMD than their ASG hybrids but a contrasting trend was evident among Pioneer hybrids. Stover moisture concentrations were greater in HSG compared with ASG hybrids from both companies but this greater moisture concentration did not adversely affect the fermentation or aerobic stability. Therefore, the theory that higher moisture concentrations of high SG hybrids would predispose to poorer fermentations was not supported. Stay-green ranking and hybrid source had little or no effect on silage $\mathrm{pH}$ and concentrations of lactic and acetic acids and aerobic stability. Future research is needed on hybrids from several companies, grown in different climatological regions in multiple years to further elucidate effects of interactions between SG ranking and maturity of corn silages on their yield, fermentation, and nutritional value.

\section{ACKNOWLEDGMENTS}

This research was supported by funds or in-kind gifts from The Southeast Milk Check-Off (Belleview, FL), the Florida Agricultural Experiment Station (Gainesville), Pioneer Hi-Bred International Inc. (Des Moines, IA) Croplan Genetics (St. Paul, MN), and the Monsanto Company (St. Louis, MO). 


\section{REFERENCES}

Arriola, K. G., S. C. Kim, C. R. Staples, and A. T. Adesogan. 2012. Stay-green ranking and maturity of corn hybrids: 2. Effects on the performance of lactating dairy cows. J. Dairy Sci. 95:975-985.

Bal, M. A., R. D. Shaver, K. J. Shinners, J. G. Coors, J. G. Lauer, R. J. Straub, and R. G. Koegel. 2002. Stage of maturity, processing, and hybrid effects on ruminal in situ disappearance of whole-plant corn silage. Anim. Feed Sci. Technol. 86:83-94.

Bekavac, G., M. Stojakovic, D. Jockovic, J. Bocanski, and B. Purar. 1998. Path analysis of stay-green trait in maize. Cereal Res. Commun. 26:161-167.

Borrell, A. K., and G. L. Hammer. 2000. Nitrogen dynamics and the physiological basis of stay-green in sorghum. Crop Sci. 40:12951307.

Borrell, A. K., G. L. Hammer, and E. V. Oosteron. 2001. Stay-green: A consequence of the balance between supply and demand for nitrogen during grain filling? Ann. Appl. Biol. 138:91-95.

Cone, J. W., A. H. Van Gelder, H. A. Van Schooten, and J. A. M. Groten. 2008. Effects of forage maize type and maturity stage on in vitro rumen fermentation characteristics. Wageningen J. Life Sci. 55:139-154.

Crosbie, T. M. 1982. Changes in physiological traits associated with long-term breeding efforts to improve grain yield of maize. Pages 206-223 in Proc. 37th Annu. Corn and Sorghum Ind. Res. Conf., Chicago, IL. H. D. Loden and D. Wilkinson, ed. Am. Seed Trade Assoc., Washington, DC

Darby, H. M., and J. G. Lauer. 2002. Harvest date and hybrid influence on corn forage yield, quality, and preservation. Agron. J. 94:559-566.

Ettle, T., and F. J. Schwarz. 2003. Effect of maize variety harvested at different maturity stages on feeding value and performance of dairy cows. Anim. Res. 52:337-349.

Hartmann, A., and H. H. Geiger. 2001. Silage maturity-Remaining plants should not be forgotten! Effects of different maturation periods of remaining plants, energy value and digestibility. Mais $29: 76-79$

Hartmann, A., T. Presterl, and H. H. Geiger. 2000. Determination of the optimal harvest date of silage maize with low and fast stover ripening. Landbauforschung Volkenrode Sonderheft 217:86-93.

Havilah, E. J., and A. G. Kaiser. 1994. The 'stay-green' characteristic and maize silage production. Proc. Second Australian Maize Conf., Gatton, Queensland, Australia.

Holm, J. I., I. Bjorck, A. Drews, and N. G. Asp. 1986. A rapid method for the analysis of starch. Starch/Die Stärke 7:224-226.

Holmes, B. J. 2009. Silage density determinations evolving. Accessed August 20, 2011. http://www.agriview.com/articles/2009/11/19/ crop_news/crops04.txt.

Holmes, B. J., and R. E. Muck. 2011. Packing bunkers and piles to maximize forage preservation. Accessed August 31, 2011. http:// www.uwex.edu/ces/crops/uwforage/PackingBunkersPiles.pdf.

Kim, S. C., and A. T. Adesogan. 2006. Influence of ensiling temperature, simulated rainfall and delayed sealing on the fermentation characteristics and aerobic stability of corn silage. J. Dairy Sci. 89:3122-3132

Lauer, J. 1998. Corn kernel milk stage and silage harvest moisture. Field Crops 28:5-18. Proc. 1998 Forage Symp. Madison, WI. Accessed September 9, 2010. http://corn.agronomy.wisc.edu/AA/ A018.aspx.
Meisser, M., and G. Weiss. 2003. The importance of factors of variation on the nutritive value of silage maize. Rev. Suisse Agric. 35:5-10.

Ministry of Agriculture, Fisheries and Food. 1986. The Analysis of Agricultural Materials. Reference Book 427. Ministry of Agriculture, Fisheries and Food, HMSO, London, UK.

Moon, N. J. 1983. Inhibition of the growth of acid-tolerant yeasts by acetate, lactate, and propionate and their synergistic mixtures. J. Appl. Bacteriol. 55:453-460.

Muck, R. E., and J. T. Dickerson. 1988. Storage temperature effects on proteolysis in alfalfa silage. Trans. ASAE 31:1005-1009.

Neylon, J. M., and L. Kung Jr. 2003. Effects of cutting height and maturity on the nutritive value of corn silage for lactating cows. J. Dairy Sci. 86:2163-2169.

Noel, R. J., and L. G. Hambleton. 1976. Collaborative study of a semiautomated method for determination of crude protein in animal feeds. J. Assoc. Off. Anal. Chem. 59:134-140.

O'Kiely, P., R. E. Muck, and P. L. O'Connor. 1987. Aerobic deterioration of alfalfa and maize silage. J. Irish Grassl. Anim. Prod. Assoc. 21:145. (Abstr.)

Pahlow, G., and E. Zimmer. 1985. Effect of a lactobacillus inoculant on fermentation and aerobic stability of grass silage. Pages 2431 in Proc. 15th Int. Grassl. Congr., Kyoto, Japan. Institute of Grassland and Forage Research, FAL, Braunschweig, Fed. Rep. Germany.

Rosenow, D. T., and L. E. Clark. 1981. Drought tolerance in sorghum. Pages 18-31 in Proc. 36th Ann. Corn Sorghum Indust. Res. Conf. H. D. Loden, and D. Wilkinson, ed. Corn Sorghum Indust., Chicago, IL.

Schlagheck, A., N. L Entrup, and M. Freitag., 2000. Effect of the ripening character ("stay green" / "dry down") on the in vitro digestibility of maize genotypes with regard to different parts of the maize plant. Landbauforschung Volkenrode Sonderheft 217:94-101.

Schwarz, F., and T. Ettle. 2000. Time of harvest and hybrid and their effects on chemical composition, digestibility and in situ degradability of starch in silage maize. Landbauforschung Volkenrode Sonderheft 217:102-115.

Subedi, K. D., and B. L. Ma. 2005. Nitrogen uptake and partitioning in stay-green and leafy maize hybrids. Crop Sci. 45:740-747.

Thomas, H., and C. M. Smart. 1993. Crops that stay green. Ann. Appl. Biol. 123:193-219.

Tilley, J. M. A., and R. A. Terry. 1963. A 2-stage technique for the in vitro digestion of forage crops. J. Br. Grassl. Soc. 18:104-111.

Van Soest, P. J., J. B. Robertson, and B. A. Lewis. 1991. Methods for dietary fiber, neutral detergent fiber and nonstarch polysaccharides in relation to animal nutrition. J. Dairy Sci. 74:3583-3597.

Wiersma, D. W., P. R. Carter, K. A. Albrecht, and J. G. Coors. 1993 Kernel milk line stage and corn forage yield, quality and dry matter content. J. Prod. Agric. 6:94-99.

Wilkinson, J. M., and J. Hill. 2003. Effect on yield and dry-matter distribution of the stay-green characteristics in cultivars of forage maize grown in England. Grass Forage Sci. 58:258-264.

Wyss, U. 2003. Influence of different maize varieties on aerobic stability of silage. Rev. Suisse Agric. 35:11-15.

Zorn, R. L. G., H. A. Schooten, and H. van Laar. 2008. Effect of silage maize hybrid (dry down vs. stay green) on dairy cow performance. Page 876 in Biodiversity and Animal Feed: Future Challenges for Grassland Production. Proc. 22nd Gen. Mtg. Eur. Grassl. Fed., Uppsala, Sweden. 